\title{
PEMETAAN POROSITAS PADA LAPISAN RESERVOIR KARBONAT DENGAN MENGGUNAKAN METODE SEISMIK INVERSI
}

\author{
Bambang Harimei S. ${ }^{*}$, Irnah Salahuddin ${ }^{1}$, Hasanuddin ${ }^{1}$

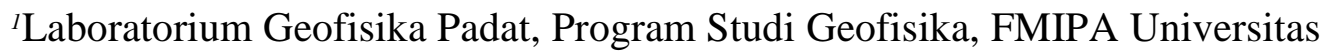 \\ Hasanuddin, Makassar \\ *Penulis koresponden. Alamat email: bambang_harimei2004@yahoo.com
}

\begin{abstract}
Abstrak
Telah dilakukan pemetaan porositas pada lapisan reservoir karbonat yang berada pada formasi Melati menggunakan metode inversi seismik berbasiskan model pada data seismic 3D. Dari hasil inversi yang dilakukan diperoleh nilai impedansi akustik antara 17000-5000 (ft.g/s.cc) dengan nilai porositas antara 10-17\% dimana daerah yang memiliki porositas antara 16-17 \% termasuk dalam skala porositas yang baik yang memungkinkan dilakukan pengembangan sumur pada daerah tersebut.
\end{abstract}

Kata Kunci: reservoir karbonat, porositas, inversi seismik berbasis model.

\begin{abstract}
Experimentally porosity mapping at carbonate reservoir layer of Tuban formation using seismic inversion model based on 3D data seismic have been done. From this inversion method yielding acoustic impedance value between 17000-5000 (ft.g/s.cc) and its porosity value between 10-17 \% where the area with porosity between 16-17\% belonging into good porosity scale that enable to do well development at that area.
\end{abstract}

Keywords: carbonate reservoir, porosity, seismic inversion model based

\section{Pendahuluan}

Batuan karbonat termasuk batuan klastik, Adapun karakter dari batuan klastik adalah porositasnya tergantung pada tekanan diferensial. Tekanan diferensial terjadi oleh karena adanya perbedaan tekanan antara overburden dan tekanan interstitial. Sebagai akibatnya porositas menurun bersamaan dengan peningkatan tekanan differensial dalam proses yang irreversible. Kehadiran hidrokarbon yang mempunyai densitas dan kecepatan yang lebih rendah dari pada air akan mengakibatkan turunnya IA batuan reservoir.

Impedansi akustik dipengaruhi langsung oleh litologi, porositas, kandungan fluida, kedalaman, tekanan, dan temperatur. Oleh karena itu $A I$ dapat digunakan sebagai 
indikator litologi, porositas, juga dapat digunakan untuk mengidentifikasi keberadaan hidrokarbon. Karena keunggulan sifat impedansi akustik ini lebih baik dalam menggambarkan sifat fisis bawah permukaan dibandingkan data seismik konvensional, maka dilakukan usaha untuk mendapatkan nilai impedansi akustik dari data seismik, yang dikenal sebagai inversi post-stack data seismik Metode seismik inversi merupakan suatu metoda pemodelan kebelakang (reverse modeling) dimana dilakukan proses mengubah data seismik yang berupa kumpulan nilai-nilai amplitudo ke dalam kumpulan nilai impedansi akustik (IA) yang nantinya akan digunakan dalam mengekstrak distribusi porositas dari batuan reservoir. Sehingga dengan melakukan inversi dan pemodelan impedansi akustik pada Formasi Kujung Cekungan Tuban ini dapat memberikan informasi seputar reservoar pada formasi tersebut berupa arah penyebarannya baik secara vertikal maupun lateral, sehingga dapat digunakan untuk manajemen reservoar lebih lanjut.

Metode Seismik Inversi telah dilakukan oleh Ariadmana, Y., 2006 seismik yang dilakukan pada Formasi Baturaja, Lapangan Raudat Cekungan Sunda yang bertujuan untuk memperkirakan karakter dan penyebaran reservoar lapangan tersebut. Nilai impedansi akustik yang diperoleh dikontrol oleh porositas total, kenaikan prositas total akan menurunkan nilai impedansi akustik, dan sebaliknya. Kualitas reservoar pada Formasi Baturaja diketahui dikontrol oleh porositas mikro. Hasil inversi data seismik menunjukkan penyebaran reservoarnya berada pada bagian atas formasi. Distribusi resevoar yang relatif mengikuti arah orientasi sesar menunjukkan bahwa sesar tersebut telah meningkatkan kualitas reservoar. Konversi nilai porositas dari impedansi akustik dilakukan untuk mendapatkan parameter yang langsung berhubungan dengan kualitas reservoar. Hubungan linier antara porositas dan impedansi akustik menunjukkan simpangan data yang tinggi, sehingga akan menghasilkan nilai porositas hasil konversi dengan kesalahan yang cukup berarti. Reservoar dengan kualitas yang baik mempunyai nilai impedansi akustik dari (15.000-20.000) ft*g/cc dengan perkiraan nilai porositas berkisar dari (19-27)\%

Dalam penelitian ini dibatasi pada pembuatan penampang akustik impedansi yang merupakan hasil inversi berbasis model, kemudian dikorelasikan dengan data porositas yang diperoleh dari sumur. Tujuan yang hendak dicapai dalam penelitian menentukan daerah porous yang berpotensi sebagai reservoar hidrokarbon pada lapangan "melati" berdasarkan nilai impedansi akustik dan porositas sumur di sekitarnya.

\section{Metodologi}

\section{Lokasi Penelitian}

Penelitian ini dilakukan dengan menggunakan data-data dari PT. PERTAMINA dengan obyektif Formasi Kujung, Cekungan Tuban, yang selanjutnya diberi nama Lapangan "Melati". Cekungan Tuban merupakan cekungan yang terletak di sekitar Pulau Jawa Timur tepatnya berada di Kabupaten Bojonegoro TAC (Technical Asistance Contact) dan blok "West Tuban" milik JOB PPEJ.

\section{Tatanan Staetegrafi}

Penampang Seismik Melintang memberikan informasi tentang stratigrafi cekungan Jawa Timur dan sekitarnya (Lihat Gambar 1.1). 


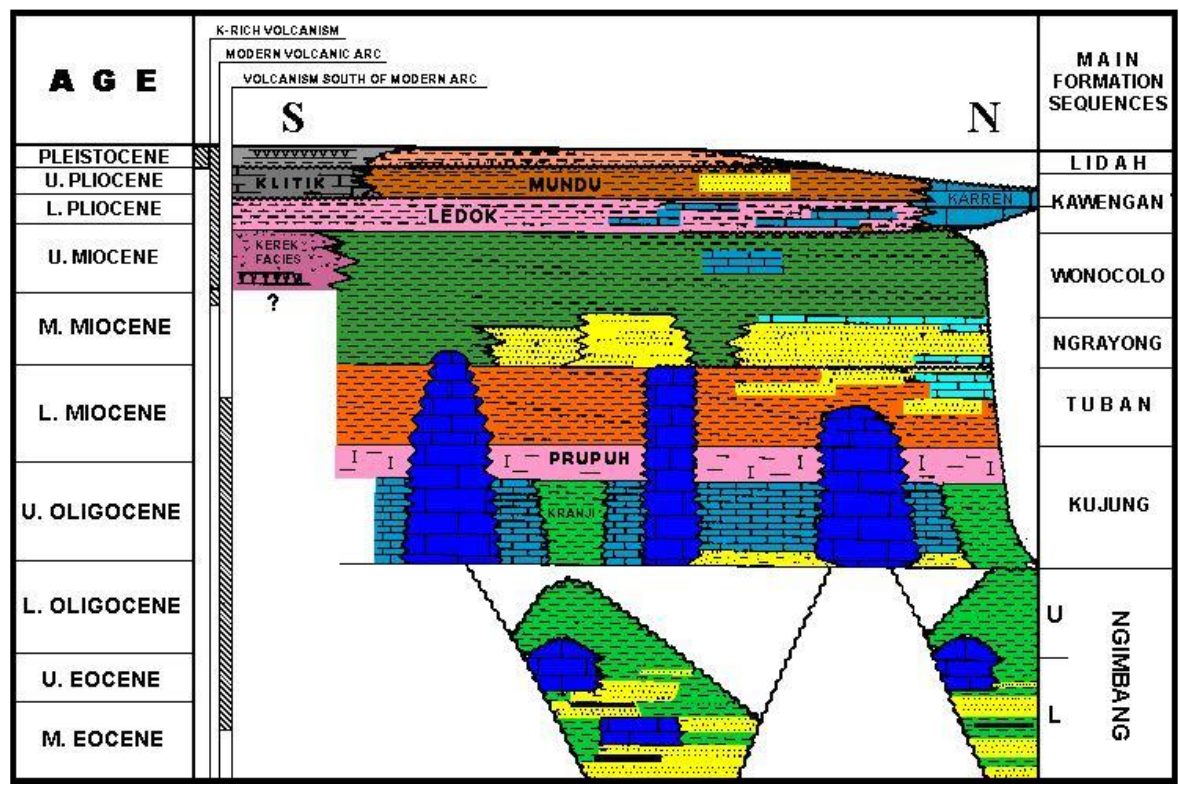

Gambar 1 Diagram Kronostratigrafi Cekungan Kunjung (JOB PPEJ)

Gambar 1 memperlihatkan urutan stratigrafi batuan Tersier di Cekungan Salawati telah ditulis oleh Soeparyadi (1976), Gambar 1.2 yang memperlihatkan urutan-urutan sejarah pengendapan di cekungan ini.

\section{Basement}

Basement yang dicirikan dengan lipatan batuan sedimen. Kemungkinan hal ini berhubungan dengan metasedimen awal Jaman PreTersier. Batuan pra-Tersier yang telah teridentifikasi dari data sumur pemboran eksplorasi adalah batuan beku granit, batuan meta-sedimen dan batuan metamorf.. Formasi Tuban ini tertembus dalam sumur-sumur pemboran SKW-1 dan SKW-2. (Pireno, 2008).

\section{Formasi Kujung}

Ketidakselarasan pada basemen dicirikan dengan refleksi yang kuat yang mengindikasikan lapisan karbonat Formasi Kujung. Tidak ada sumur yang mencapai formasi ini.

Formasi Tuban
Formasi Karbonat Tuban secara selaras menumpang di atas Formasi Kujung. Karakter seismik yang terlihat pada karbonat ini menunjukan perkembangan karbonat terumbu dengan refleksi mound pada beberapa perulangan.

\section{Formasi Ngrayong}

Batupasir Ngrayong secara tidak selaras menumpang di atas Formasi Karbonat Tuban. Berdasarkan penampang seismik yang ada, formasi ini dicirikan dengan refleksi yang relatif kuat dan saling sejajar. Tiga sumur telah mencapai formasi ini. Bagian terbawah dari lapisan ini menunjukan lapisan-lapisan yang saling onlap pada Formasi Tuban. Hal ini dapat diinterpretasikan sebagai batas sekuen atau ketidakselarasan yang disebabkan perubahan muka air laut relatif. Zona gas yang tertahan ditemukan pada bagian terbawah formasi ini. 


\section{Formasi Wonocolo}

Batupasir Ngrayong tertutup secara selaras oleh Formasi Wonocolo. Formasi Wonocolo dicirikan dengan refleksi yang saling sejajar dan tidak begitu jelas yang menunjukan formasi batulempung. Tiga sumur di daerah penelitian telah mencapai formasi ini dan membuktikan litologi yang didominasi batulempung.

\section{Formasi Kawengan}

Formasi Kawengan diendapkan secara selaras di atas Formasi Wonocolo. Formasi Ledok dan yang lebih muda terlihat sebagai refleksi horizontal yang saling sejajar pada penampang seismik.

\section{Formasi Lidah}

Formasi Lidah merupakan formasi termuda di dalam urutan stratigrafi di daerah penelitian, sehingga banyak ditemukan endapan aluvial yang subur. Formasi ini diendapkan secara selaras di atas Formasi Kawengan.

\section{Inversi Berbasiskan Model}

Pada inversi ini dibangun model geologi yang kemudian model tersebut dibandingkan dengan data seismik, model tersebut diperbaharui secara iteratif sehingga diperoleh kesesuaian dengan data seismik dengan menggunakan metoda Generalized Linear Inversion (GLI).Metoda GLI ini menganalisa beda (error) antara output model dan data obsrvasi kemudian memperbaharui parameter model dengan cara sedemikian rupa sehingga dihasilkan output dengan beda seminimum mungkin. Dengan cara ini maka dapat dilakukan iterasi untuk mendapatkan solusi yang dirumuskan secara matematis sebagai berikut (Sukmono S, 2000):

$$
F(M)=F\left(M_{0}\right)+\frac{\delta F\left(M_{0}\right)}{\delta M} \Delta M
$$

dengan $M_{0}$ Model awal; $M$ Model geologi sebenarnya; $\Delta M$ Perubahan pada parameter model; $\quad F(M)$ Pengamatan; $\quad F\left(M_{0}\right)$ Hasil perhitungan dari model awal; $\left(\partial \mathrm{F}\left(\mathrm{M}_{0}\right)\right) / \partial \mathrm{M}$ Perubahan nilai perhitungan.

\section{Porositas}

Porositas $(\varnothing)$ didefenisikan sebagai presentasi besarnya ruang kosong dalam suatu batuan yang dapat terisi fluida terhadap besarnya volume total batuan tersebut. Persamaan porositas dapat dituliskan (Sukmono, 2000):

$\varnothing=\frac{V_{\text {ruang } \text { kosong }}}{V_{\text {total batuan }}} \times 100 \%$

Porositas bisa juga diartikan sebagai spasi antara butiran yang tak terkompaksi dengan sempurna. Secara teoritis porositas bernilai antara 0 sampai $1 \quad(0<\phi<1)$ namun dalam prakteknya karbonat memiliki porositas berkisar 10 sampai 20 persen saja.Besarnya porositas dapat diketahui melalui berbagai cara seperti pembacaan pada log listrik, log sonik log densitas dan log kecepatan. Dari persamaan Wyllie dapat dilihatkan hubungan antara densitas, kecepatan dan porositas:

$\rho_{\text {sat }}=\rho_{m}(1-\phi)+\rho_{w} S_{w} \phi+\rho_{h c}\left(1-S_{w}\right) \phi(3)$

$\Delta t_{a}=\Delta t_{m}(1-\phi)+\Delta t_{w} S_{w} \phi+\Delta t_{h c}\left(1-S_{w}\right) \phi(4)$ dengan $\rho$ densitas $(\mathrm{Kg} / \mathrm{m}), \phi$ porositas $(\%)$ $S_{w}$ water saturation $(\%)$, dan indeks $\mathrm{m}$, w, hc, matrix, water, hydrocarbon.

\section{Pengolahan Data}

Data seismik yang digunakan dalam penelitian ini berupa data seismik 3D yang terdiri dari 408 xlinedan 467 inline.

Gambar 3, 4, 5, dan 6menunjukkan penampang seismik melewati sumur SKW-1 inline 6379 xline 1288 dan SKW-2 inline 
6340 xline 12897. Sedangkan Gambar 2 memperlihatkan posisi pengambilan data, data diambil dari SKW-1 inline SKW-1 inline 6379 xline 1288 dan SKW-2 inline
6340 xline 12897. Adapun posisi SKW-1 dan SKW-2 ditandai dengan angka berwarna merah.

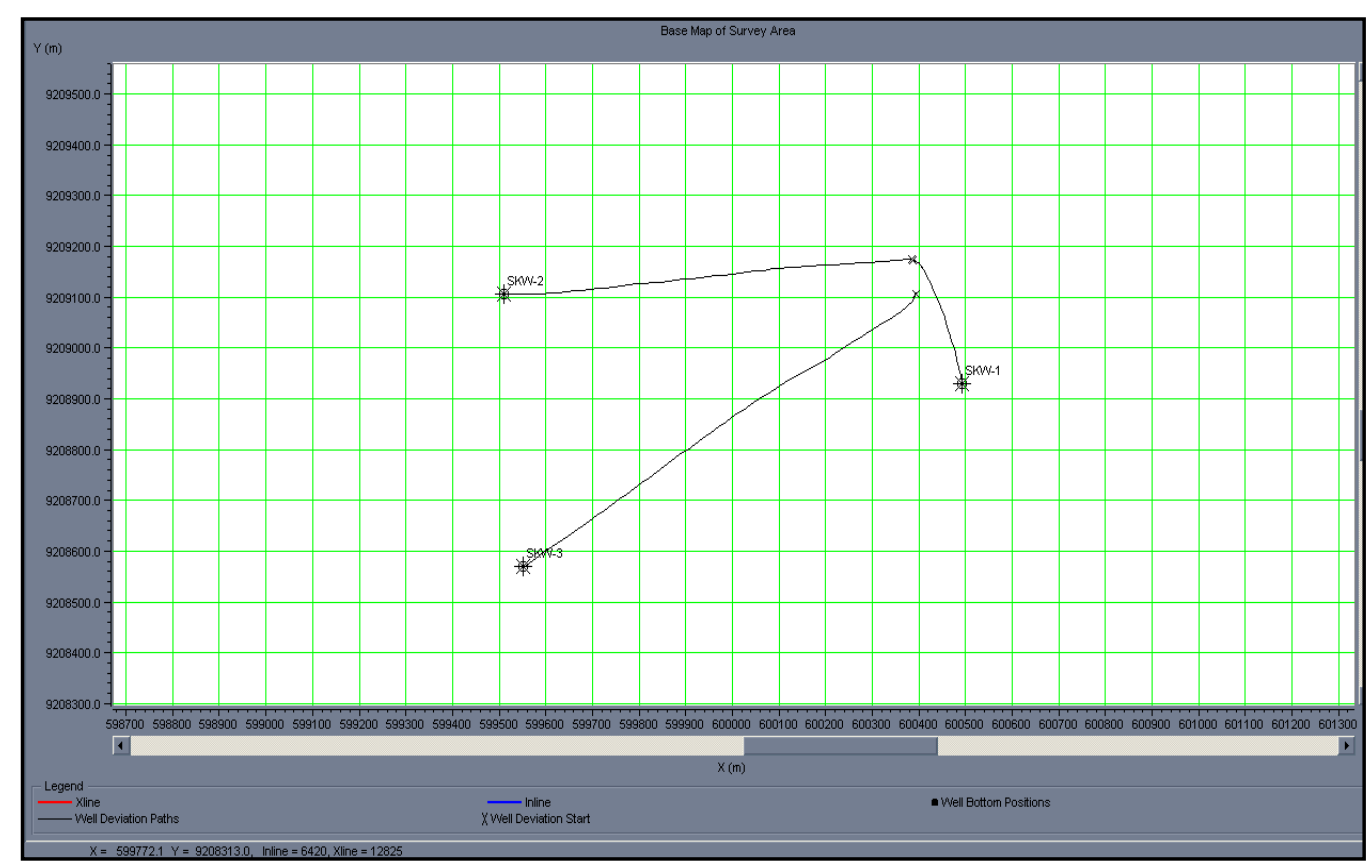

Gambar 2 Peta dasar seismik

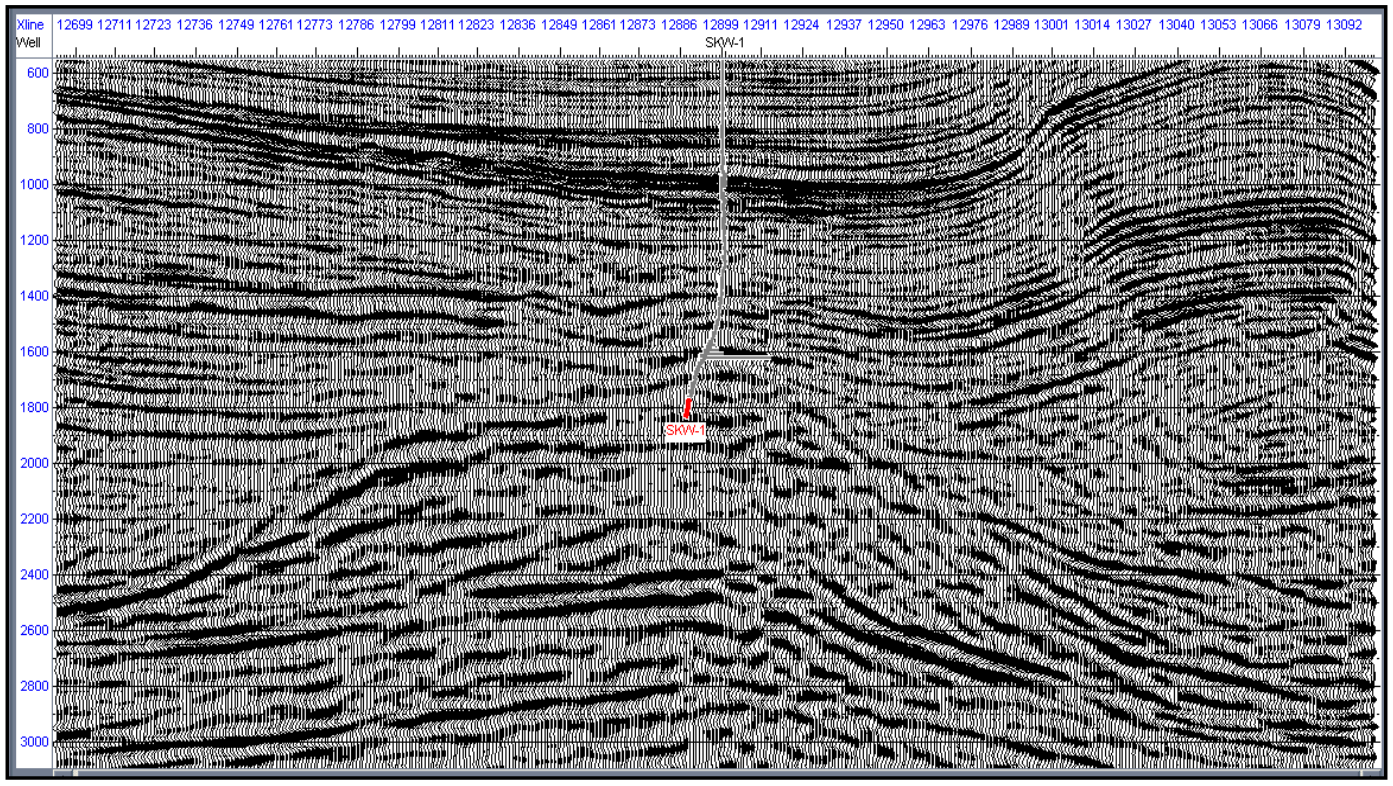

Gambar 3 Penampang seismik melewati sumur SKW-1 pada inline 6379 
Pemetaan Porositas pada Lapisan Reservoir Karbonat dengan Menggunakan ....

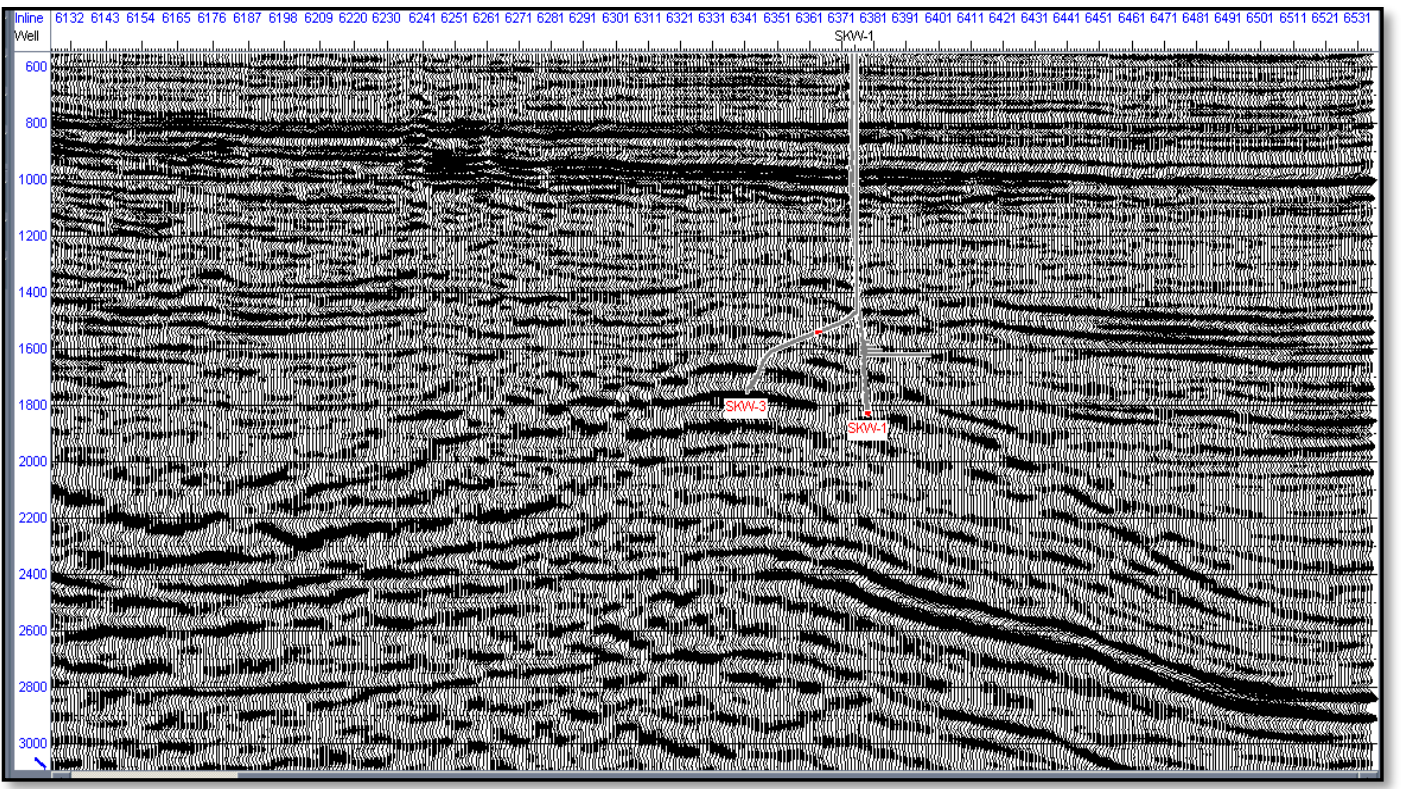

Gambar 4 Penampang seismik melewati sumur SKW-1 xline 12888

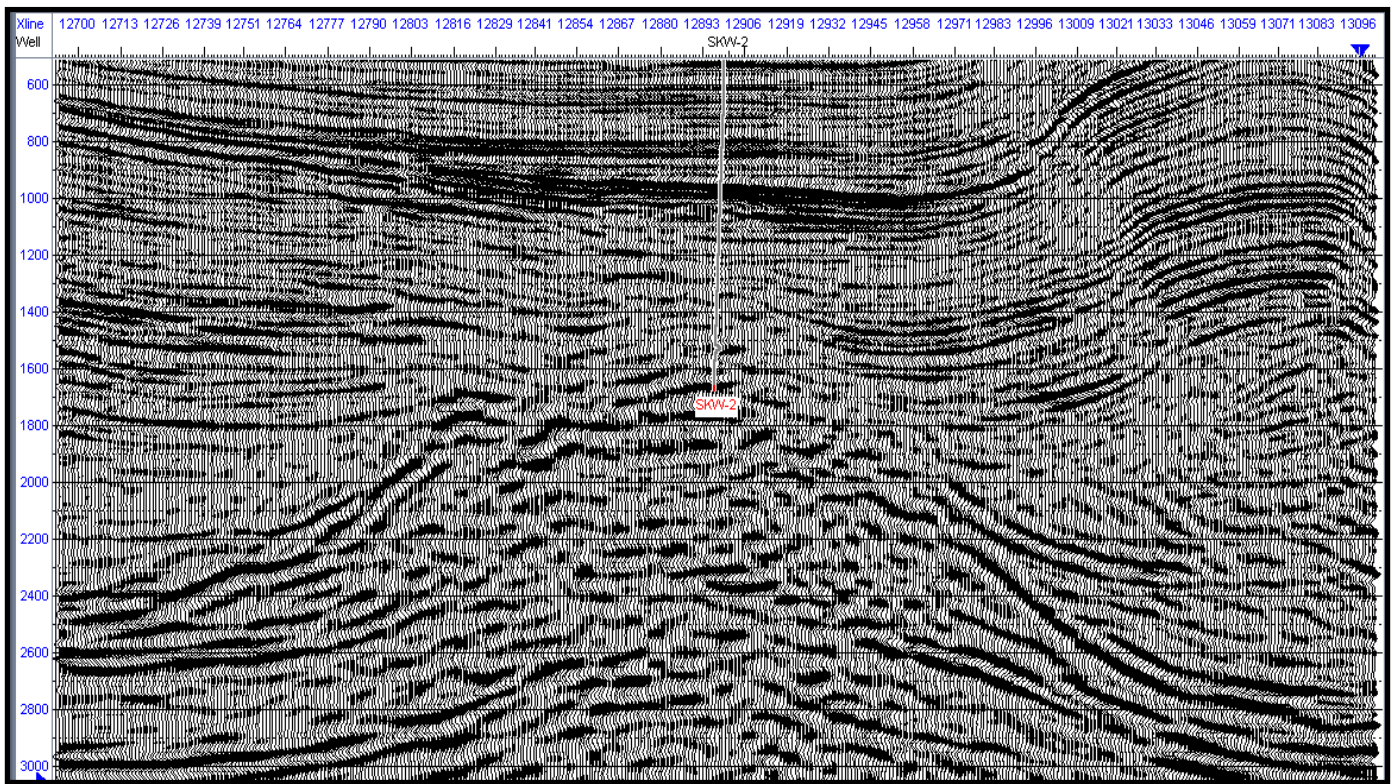

Gambar 5 Penampang seismik melewati sumur SKW-2 pada inline 6340 


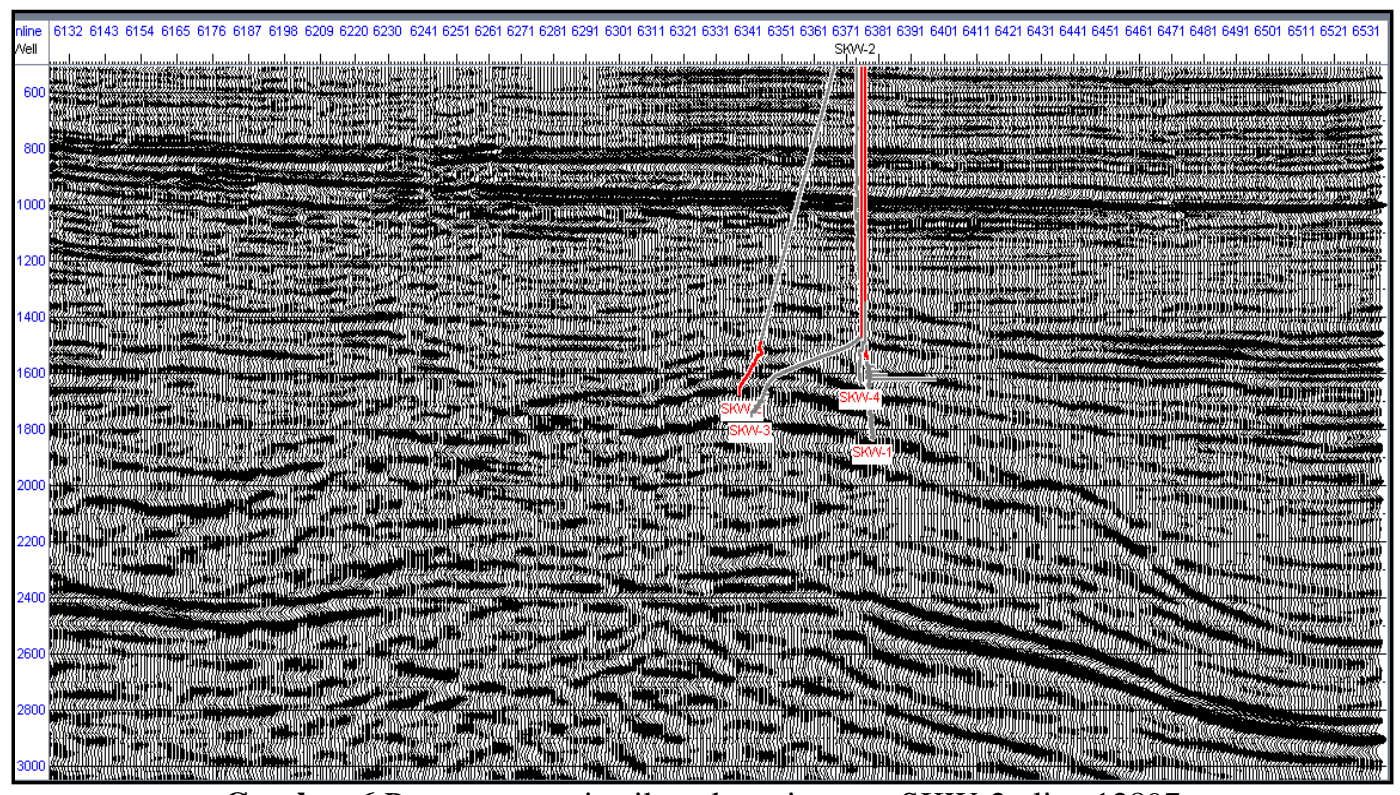

Gambar 6 Penampang seismik melewati sumur SKW-2 xline 12897

\section{Ekstraksi Wavelet.}

Ekstraksi wavelet merupakan proses yang dilakukan untuk mengestimasi bentuk gelombang dari sumber getar yang telah terkonvolusi kedalam jejak seismik. Wavelet ini akan dikonvolusikan dengan reflektifitas dari data sumur sehingga menghasilkan sintetik yang akan digunakan untuk proses korelasi dengan data seismik.Ekstraksi wavelet dilakukan dengan menggunakan informasi dari data sumur yang ada untuk mengektraksi komponen amplitudo dan fasa.

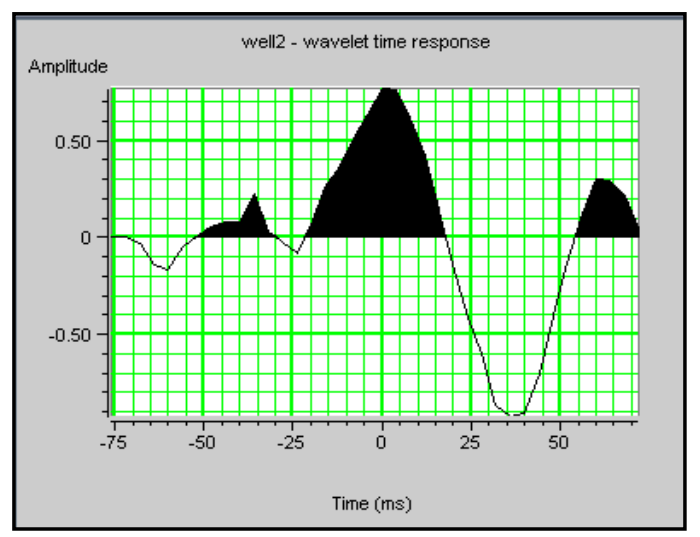

Gambar 7.a Wavelet Hasil Ekstraksi Sumur SKW-1

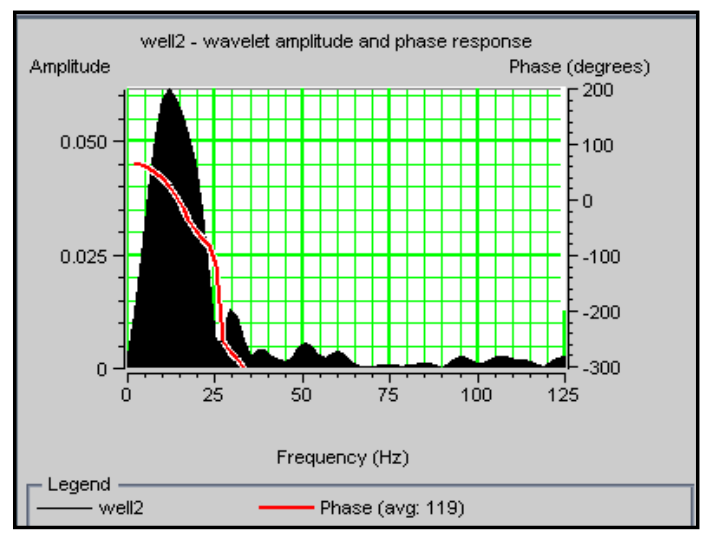

Gambar 7.b Wavelet Hasil Ekstraksi Sumur SKW-2

Gambar7 memperlihatkan ekstraksi wavelet dengan cara ini akan memberikan wavelet yang akan lebih mendekati wavelet sebenarnya dari data seismik. Ekstraksi ini dilakukan terhadap data seismik sekaligus dengan kontrol data sumur, sehingga akan memberikan wavelet dengan fasa yang tepat. Namun ekstraksi ini hanya akan memberikan hasil yang maksimal jika data sumur sudah terikat dengan baik. Ekstraksi wavelet secara statistik dan pengikatan yang baik sangat diperlukan untuk mendapatkan hasil ekstraksi wavelet secara deterministik dengan kualitas yang baik. Untuk menghasilkan sintetik dengan korelasi optimal, maka dilakukan 
shifting dan bila diperlukan maka dapat dilakukan stretch dan squeeze, akan tetapi hal tersebut tidak dianjurkan.

Pengikatan Data Sumur dengan Data Seismik (Well Seismic Tie)

Setelah melakukan proses wavelet selanjunya melakukan pengikatan data sumur dengan dara seismik. Proses ini merupakan penyesuaian kedudukan even pada jejak seismik dengan even pada data sintetik yang dihasilkan dari data sumur.
Proses ini dilakukan dengan menggeser wiggle-wigle sintetik ke posisi paling mirip dengan data seismik. Semakin tinggi harga korelasinya (mendekati angka 1) menunjukkan semakin tepat posisi sintetik terhadap data seismik (terkorelasi dengan baik). Data seismik yang dikorelasikan dengan sintetik adalah data seismik yang berupa reflektifitas gelombang $\mathrm{P}$ yaitu SKW-1 dan SKW-2.

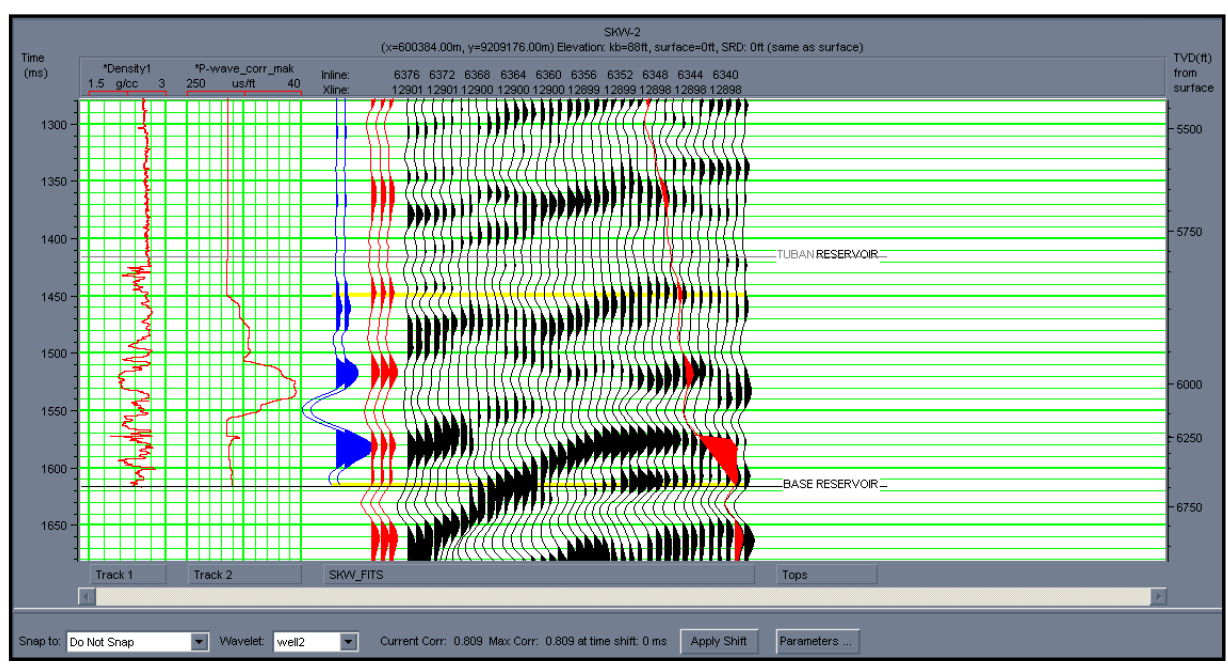

Gambar 8aWell Seismic Tie SKW-1

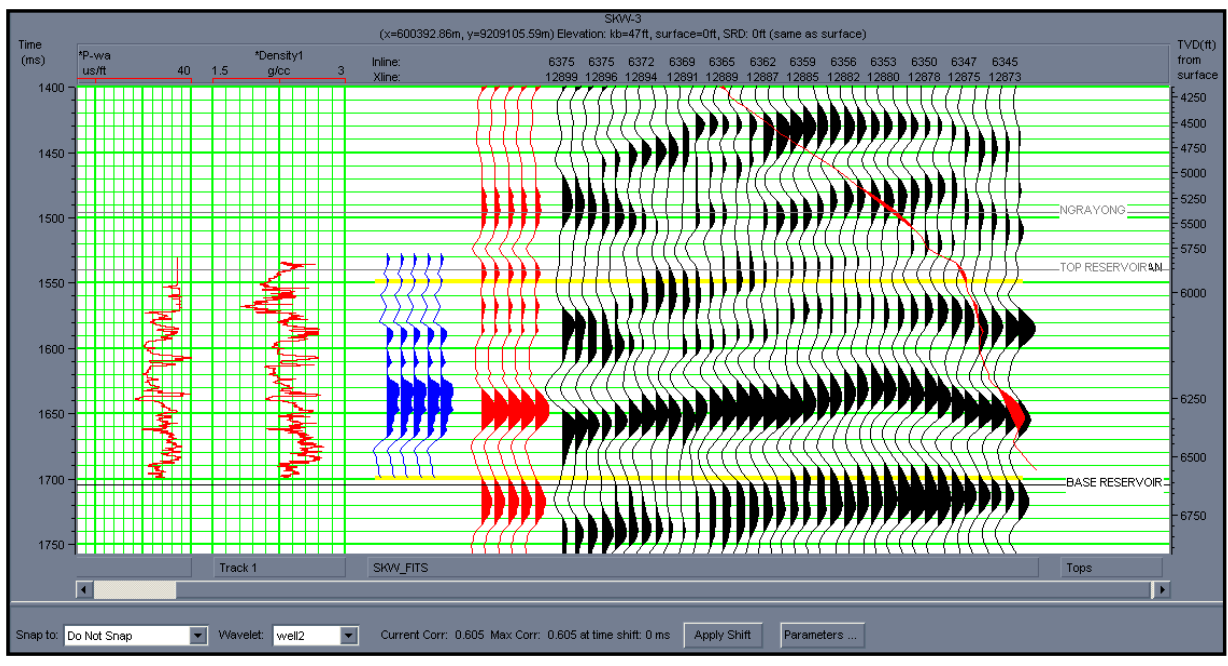

Gambar 8bWell Seismic Tie SKW-2 
Gambar 8a dan Gambar 8b memperlihatkan Well seimic Tie, dalam gambar tersebut di atas, amplitudo maksimal tidak dalam posisi lurus. Hal ini perlu adanya proses picking horizon.

\section{Picking Horizon}

Saat melakukan proses pengikatan banyak sinyal yang mengalami pelemahan untuk maksud mendudukan sinyal ke kedudukan sebenarnya langkah yang ditempuh adalah melakukan picking horizon. Di samping itu, picking berguna dalam menentukan mengetahui struktur suatu formasi atau lapisan sehingga dapat diambil kesimpulan mengenai keberadaan closure. Hasil picking ini juga akan digunakan untuk membuat model sebelum melakukan inversi seismik, horizon yang di-pick pada data seismik adalah Top Tuban Karbonat SKW-1 dan SKW-2.

\section{Pembuatan Model Awal}

Pembuatan model awal (initial model) sangat dipengaruhi oleh kualitas pengikatan data sumur dan data seismik. Oleh Karena itu pemilihan wavelet sangat mempengaruhi hasil dari model awal.



Gambar 9Model awal geologi melewati sumur SKW-1 pada inline 6379



Gambar 10 Model awal geologi melewati sumur SKW-1 pada xline 12888 


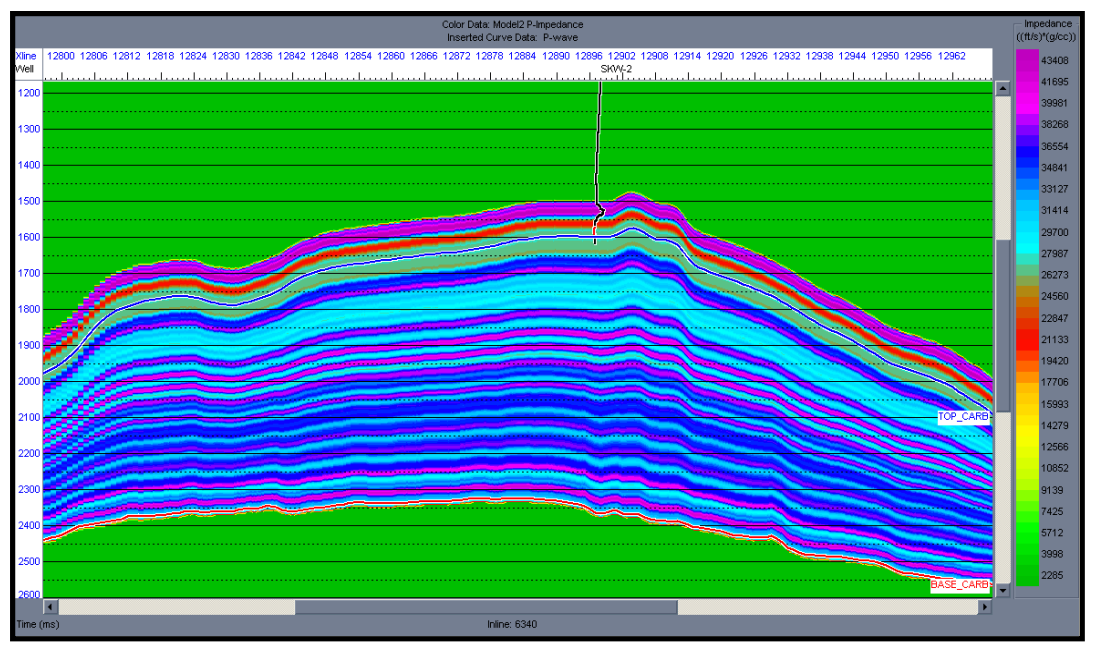

Gambar 11Model awal geologi melewati sumur SKW-2 pada inline 6340

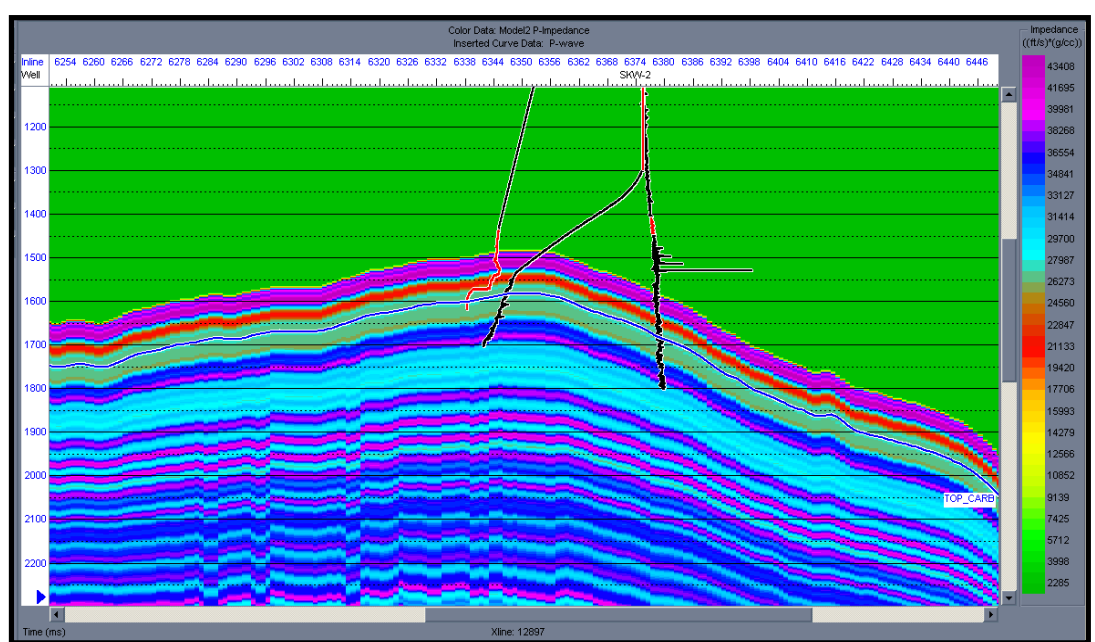

Gambar 12Model awal geologi melewati sumur SKW-2 pada xline 12897

\section{Inversi Berbasiskan Model}

Proses inversiberbasiskan model dilakukan dengan menggunakan pembatas lunak (soft constrain).pembatas ini mempunyai range nilai dari 0 sampai 1 . Jika nilai yang dipakai adalah nol maka artinya model awal diabaikan sehingga hasil akhir yang dperoleh adalah benar-benar murni dari data seismik, sedangkan nilai satu menyatakan bahwa data seismik tidak digunakan tapi hasil akhirnya berdasarkan model awal yang telah dibuat sebelumnya.

\section{Pemetaan Impedansi akustik}

Impedansi akustik (IA) adalah sifat batuan yang dipengaruhi oleh jenis litologi, porositas, kandungan fluida, kedalaman, tekanan dan temperatur. Oleh karena itu IA dapat digunakan sebagai indikator litologi, porositas, hidrokarbon, pemetaan litologi. IA dirumuskan sebagai:

$$
I A_{n}=I A_{1} \prod_{i=1}^{n-1}\left[\frac{1+K R_{1}}{1-K R_{1}}\right]
$$

Harga IA dapat diperkirakan dari amplitudo refleksinya, semakin besar amplitudo refleksinya semakin besar refleksi dan kontras IA-nya. IA seismik memberikan 
resolusi lateral dan cakupan (coverage) yang baik. Sedangkan IA sumur memberikan resolusi vertikal yang sangat baik tetapi resolusi cakupan lateralnya buruk (Sukmono S, 2000).

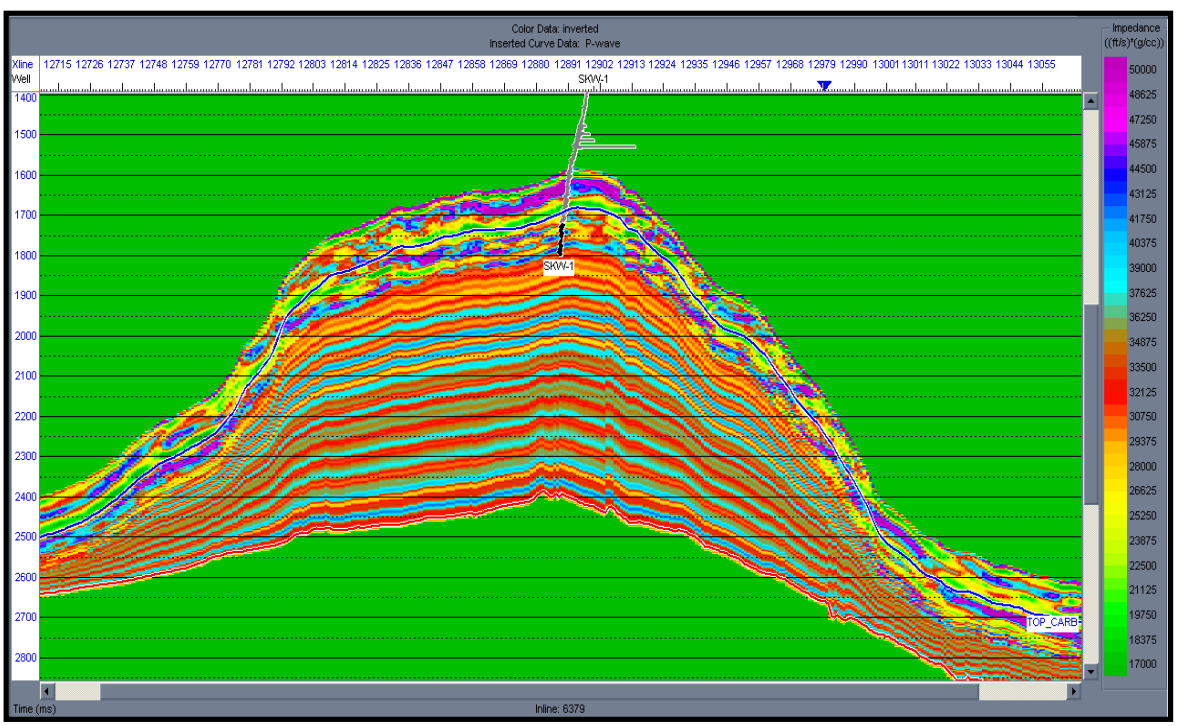

Gambar 14Penampang impedasi akustik sumur SKW-1 pada inline

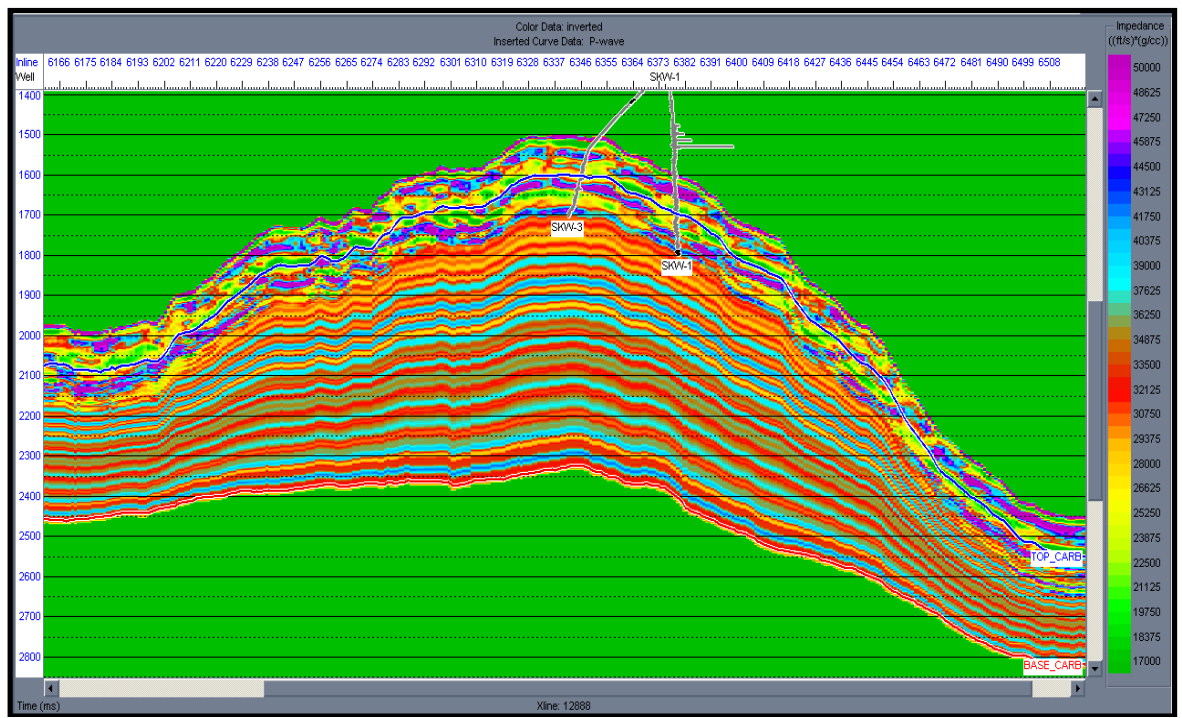

Gambar 15Penampang impedasi akustik sumur SKW-1 pada xline 


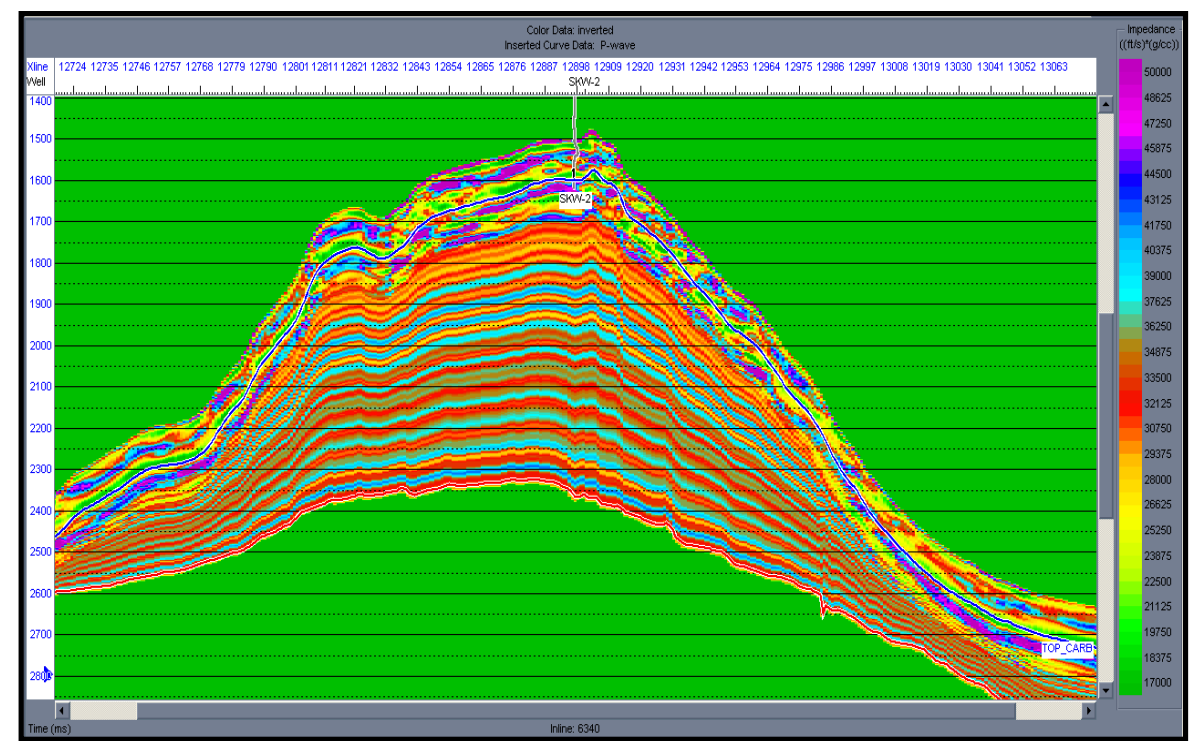

Gambar 16 Penampang impedasi akustik sumur SKW-2 inline

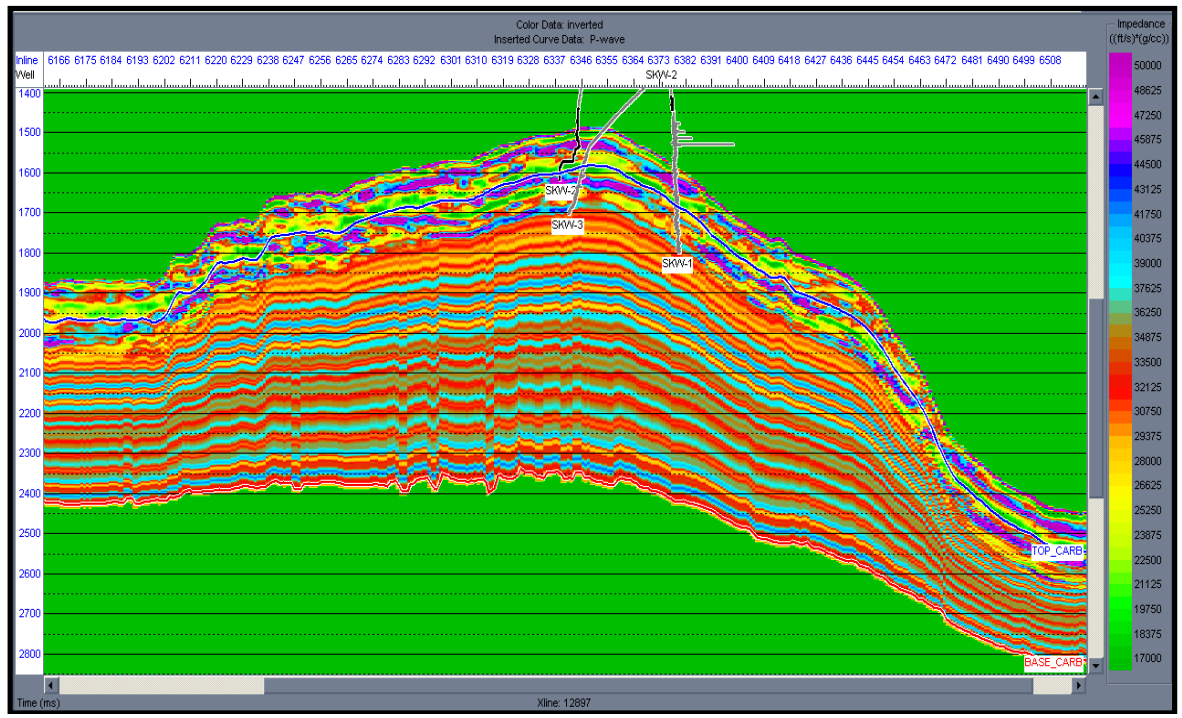

Gambar 17Penampang impedasi akustik sumur SKW-2 xline

Pada Gambar 14 dan Gambar 16 memperlihatkan harga Impedansi Akustik yang relatif tinggi ditunjukkan dengan indeks warna ungu dengan nilai 50000 (ft.g/s.cc) sedangkan harga Impedansi Akustik yang rendah ditunjukkan dengan indeks warna hijau dengan nilai 17000 (ft.g/s.cc), impedansi akustik rendah berada di bawah Top reservoir dengan nilai impedansi akustik antara 17000-25000 (ft.g/s.cc) sedangkan Top karbonat memperlihatkan nilai Impedansi Akustik yang tinggi (indeks warna ungu) dengan nilai Impedansi Akustik 5000(ft.g/s.cc). Perbedaan nilai Impedansi Akustik yang begitu besar menunjukkan adanya batas lapisan antara batu pasir dan karbonat. Time slice $10 \mathrm{~ms}$ di bawah time $1635 \mathrm{~ms}$ yang merupakan bidang batas antara air dan minyak (OWC) memperlihatkan daerah yang memiliki nilai Impedansi Akustik yang rendah (low impedance) dengan nilai antara 17000-25000(ft.g/s.cc). SKW-2terletak pada daerah yang memiliki nilai Impedansi 
Akustik rendah (17000-25000 ft.g/s.cc) sedangkan 1 sumur yaitu SKW-1 terletak pada daerah yang nilai Impedansi Akustik tinggi (5000 ft.g/s.cc).

\section{Pemetaan Porositas}

Model porositas ini dihasilkan dengan cara mencari hubungan kelinieran antara hasil impedansi akustik dan porositas. Hubungan kelinieran ini didapatkan dari hasil crossplot antara impedansi akustik hasil inversi dengan porositas yang merupakan properti sumur. Hasil analisis ini kemudian akan digunakan untuk membuat penampang porositas.

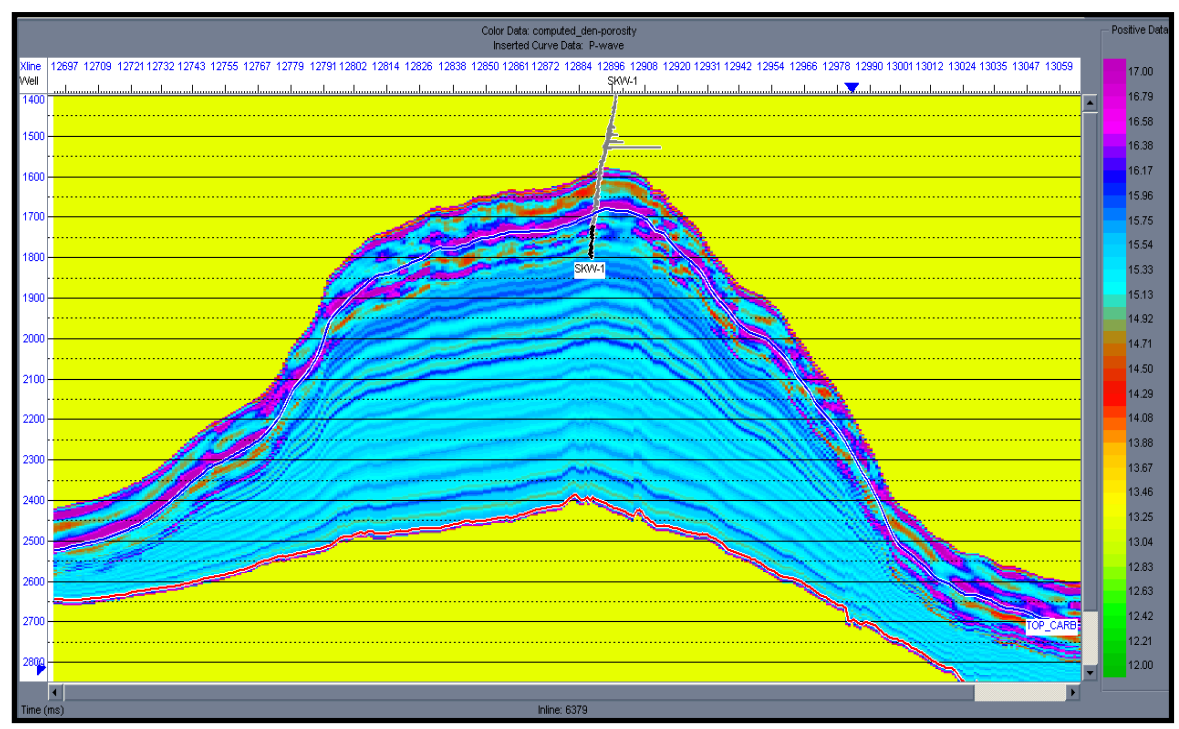

Gambar 18Penampang porositas melewati sumur SKW-1 inline

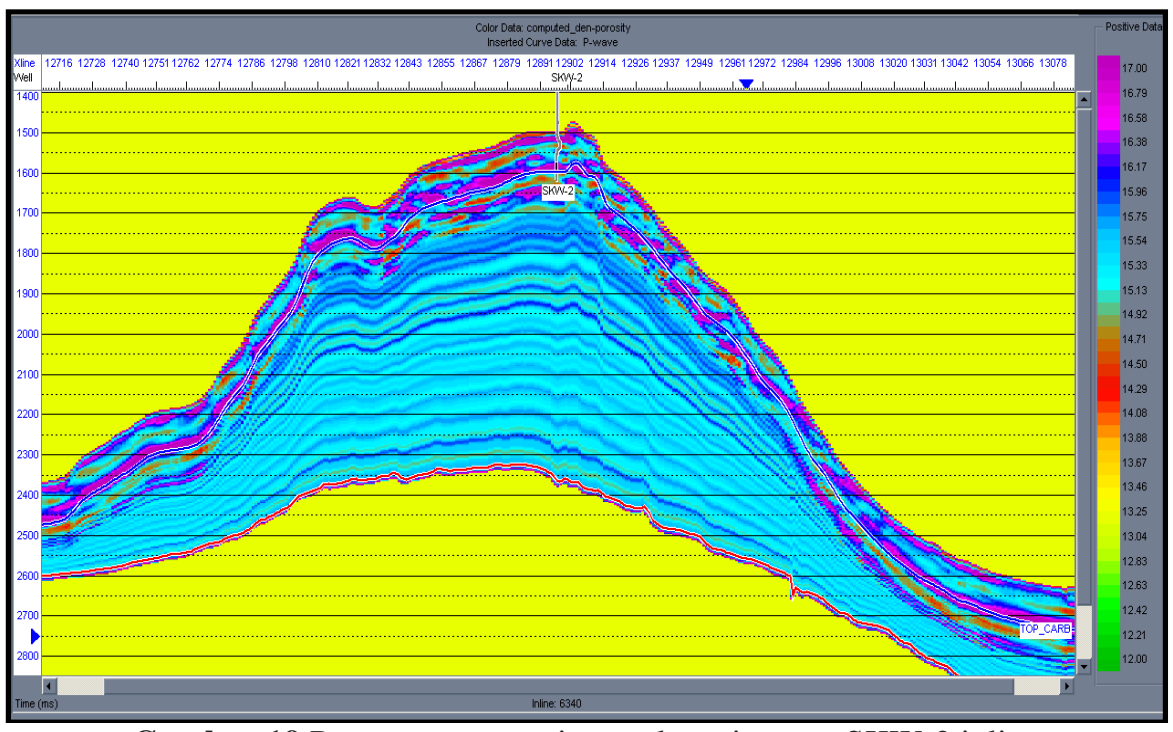

Gambar 19 Penampang porositas melewati sumur SKW-2 inline

Pada Gambar 18dan Gambar 19 memperlihatkan bahwa penampang porositas yang dihasilkan memperlihatkan sebaran nilai porositas pada top karbonat dengan nilai porositas antara $12-17 \%$. Gambar 15 dan Gambar 18 menunjukkan 
daerah yang poros tepat berada di bawah Top karbonat dengan nilai porositas antara 16-17\% ditunjukkan dengan indeks warna ungu, bagian atas Top karbonat ini juga memperlihatkan nilai porositas yang sama (16-17\%) hal ini disebabkan karena lapisan yang berada di atas batuan karbonat adalah batu pasir yang merupakan batuan reservoir tetapi analisa dibatasi hanya pada reservoir karbonat saja. Time slice $10 \mathrm{~ms}$ dibawah $1635 \mathrm{~ms}$ yang dilakukan pada penampang porositas memperlihatkan daerah yangmemiliki nilai porositas tinggi antara 16-17\% (indeks warna ungu). Dari hasil time slice dapat diketahui bahwa daerah yang memiliki porositas tinggi dengan nilai antara 16-17\% (skala baik) berada pada Utara-Selatan. Timur-Barat sumur SKW-2 dan sebelah Barat sumur SKW-2 berada pada da.rah yang nilai porositasnya antara 16-17\% (porositas baik), sedangkan sumur SKW-1 berada pada daerah yang nilai porositasnya antara $13.8-14.7 \%$ yang termasuk dalam skala cukup. Hasil crossplot yang digunakan mencari hubungan kelinieran antara Impedansi Akustik dan porositas memperlihatkan bahwa nilai Impedansi Akustik berbanding terbalik dengan nilai porositas, semakin kecil nilai Impedansi Akustik maka nilai porositas semakin besar.

\section{Kesimpulan}

Dari analisa yang dilakukan dapat dibuat beberapa kesimpulan sebagai berikut:

1. Formasi Tuban memiliki nilai porositas dengan persentase antara 12-17\%, berdasarkan skala penentuan nilai porositas diketahui bahwa nilai porositas $16-17 \%$ termasuk dalam skala porositas baik (good porosity).

2. Daerah yang memiliki porositas bagus (good porosity) berada pada inline 6292 - inline 6376 dan xline 12849 - xline12916 yang merupakan prospek sebagai cadangan reservoir baru dimana daerah tersebut memiliki nilai porositas yang baik dengan persentase $16 \%-17 \%$.

\section{Saran}

Hasil analisa yang maksimal sebaiknya didukung dengan analisa inversi lainnya seperti spars spike karena karakterisasi berdasarkan IA memiliki keterbatasan dalam membedakan antara efek litologi dan fluida.

\section{Daftar Pustaka}

Ariadmana Y,2006 Seismik Invesi pada formasi Baturaja. JOB PPEJ Jakarta

Russel, B .H., 1988, Strata Theory, Hampson Russel Software Services Ltd. Calgary, Alberta.

Sukmono, S., 2000. Seismik inverse untuk karakterisasi reservoar. Institut Teknologi Bandung. Bandung.

Soeparyadi, 1976, Diagram Kronogstarigafi Cekungan Kunjung >Lemigas Jakarta 